\title{
PRO DAN KONTRA UNDANG-UNDANG NOMOR 8 TAHUN 2016 TENTANG PENYANDANG DISABILITAS
}

\author{
Denda Devi Sarah Mandini1 \\ 1Program Studi Ilmu Pemerintahan, Fakultas Ilmu Sosial dan Ilmu Politik, \\ Universitas 45 Mataram, Indonesia \\ Email Korespondensi: dendadevi95@yahoo.com
}

\begin{abstract}
Abstrak
Pada tulisan ini penulis akan membahas pro kontra proses pembahasan Undangundang no. 8 tahun 2016 mengingat seringkali terjadi diskriminasi yang dialami oleh para penyandang disabilitas baik itu susahnya akses untuk fasilitas umum, dikucilkan, dll. Sehingga pada tulisan ini penulis akan melihat apakah aturan hukum yang baru sesuai dengan kebutuhan para penyandang disabilitas, dan ketika aturan ini dibuat apakah para legislator melibatkan penyandang disabilitas dalam proses pembuatan undang-undang, dan sebenarnya apa yang menjadi alasan para legislator untuk mengubah peraturan ini. Metode yang digunakan pada tulisan ini menggunakan hukum normatif, data yang digunakan bersumber dari hasil penelitian terdahulu, berita atau surat kabar, UU. Hasil tulisan ini menunjukkan bahwa proses pembuatan UU disabilitas didasarkan pada kebutuhan para penyandang disabilitas disamping itu pada prosesnya banyak aktor- para akademisi, LSM yang terlibat untuk mengetahui kebutuhan dari para penyandang disabilitas.

Kata Kunci: Pro Kontra, Penyandang Disabilitas, UU No. 8 Tahun 2016.
\end{abstract}

\begin{abstract}
In this paper the author will discuss the pros and cons of the deliberation process of Law no. 8 of 2016 the hospitality of the nation that caters to people with disabilities, whether it is difficult access to public facilities, being excluded, etc. So that in this paper the author will look at whether the new law rules suit the needs of persons with disabilities, and when this rule is made, whether legislators are involved with people with disabilities in the law-making process, and what are the reasons the legislators change this regulation. . The method used in this paper uses normative law, the data used comes from the results of previous research, news or newspapers, laws. The results of this paper indicate that the making of laws is based on the needs of persons with disabilities. In addition, in the process, many actors, NGOs are involved to see the needs of persons with disabilities.
\end{abstract}

Keywords: Pros and Cons, Persons with Disabilities, Law no. 8 of 2016.

\section{PENDAHULUAN}

Semua orang seharusnya sepakat bahwa penyandang disabilitas perlu mendapatkan harkat dan martabat yang sama seperti halnya manusia normal. 
Keberadaan mereka, bagi sebagian orang dianggap sebelah mata. Seperti halnya dalam kehidupan sosial, pendidikan, maupun pekerjaan. Hal tersebut merupakan hal yang fundamental dalam memperoleh hak asasi manusia. Penyandang disabilitas juga memiliki hak perlindungan, keadilan, kesetaraan fasilitas-fasilitas yang dapat penunjang. Diskriminasi terhadap penyandang disabilitas merupakan pelanggaran terhadap HAM Harus ada hukum yang jelas atas perlindungan terhadap penyandang disabilitas, jaminan terhadap HAM mereka.

Aturan hukum yang dibuat oleh pemerintah harus mewakili suara dari penyandang disabilitas, karena mereka lah yang lebih tau kebutuhannya. Bentuk perhatian terhadap penyandang disabilitas bukan hanya ditunjukan oleh pemerintah dalam negeri, tetapi dari PBB sendiri telah menetapkan setiap tanggal 3 Desember dijadikan sebagai Hari Penyandang Cacat Sedunia (sesuai dengan Ratifikasi Konvensi Hak Penyandang Disabilitas, istilah penyandang cacat diganti menjadi penyandang disabilitas). Dengan adanya hari bagi penyandang disabilitas ini, maka bentuk perhatian terhadap penyandang disabilitas bukan hanya dari nasional tetapi menjadi perhatian internasional terhadap persoalan yang dihadapi pada penyandang disabilitas.

Persoalan para penyandang disabilitas, sebenarnya adalah persoalan kita bersama. Pelayanan publik ataupun fasilitas umum terkadang ada yang tidak ramah akan penyandang disabilitas. Di Indonesia sendiri, para penyandang disabilitas hidup dalam kondisi yang rentan, terbelakang, dan dalam kondisi ekonomi yang rendah. Mereka sering mendapatkan kesulitan, hambatan dalam berhadapan dengan sosial dan publik. Bagi beberapa orang penyadang disabilitas adalah orang-orang yang lemah. Penyandang disabilitas sebenarnya memiliki martabat yang sama dengan manusia lainnya, bukan menjadi objek belas kasihan.

Tugas pemerintah adalah memberikan jaminan atas kesetaraan, kesamaan hak, serta dilibatkan dalam penyelenggraan negara, mereka berhak untuk berpartisipasi dalam negara. Maka untuk itu perlu suatu aturan hukum yang jelas dari pemerintah, agar hak-hak dari penyandang disabilitas 
tetap dilindungi. Maka untuk itu pemerintah pada tahun 2016, mengeluarkan Undang-Undang Nomor 8 Tahun 2016 Tentang Penyandang Disabilitas, yang semulanya diatur pada Undang-Undang Nomor 4 Tahun 1997 Tentang Penyandang Cacat.

Tujuan dari penulisan ini adalah melihat apakah aturan hukum yang baru sesuai dengan kebutuhan para penyandang disabilitas, dan ketika aturan ini dibuat apakah para legislator melibatkan penyandang disabilitas dalam proses pembuatan undang-undang, dan sebenarnya apa yang menjadi alasan para legislator untuk mengubah peraturan ini.

Metode yang digunakan pada tulisan ini jenis penelitian hukum normatif dengan melakukan studi litelatur, dan perundang-undangan yang berhubungan dengan objek penelitian. Sumber data yang digunakan data sekunder terdiri dari penelitian terdahulu, buku-buku, jurnal ilmiah, media masa, internet, koran, majalah, serta referensi lainnya.

Kebijakan dapat didefinisikan sebagai serangkaian rencana program, aktivitas, aksi, keputusan, sikap, untuk bertindak maupun tidak bertindak yang dilakukan oleh para pihak (aktor-aktor), sebagai tahapan untuk penyelesaian masalah yang dihadapi. Penetapan kebijakan merupakan suatu faktor penting bagi organisasi untuk mencapai tujuannya (Iskandar, 2012).

Menurut Said Zainal Abidin (2004: 56-59) dalam (Anggara, 2018), tidak semua kebijakan publik mempunyai prioritas yang sama untuk diproses. Hal tersebut ditentukan oleh proses penyaringan melalui serangkaiankriteria. Berikut ini kriteria yang dapat digunakan dalam menentukan kebijakan.

a. Efektivitas, mengukur suatu alternatif sasaran yang dicapai dengan suatu alternatif kebijakan dapat menghasilkan tujuan akhir yang diinginkan.

b. Efisien, dana yang digunakan harus sesuai dengan tujuan yang dicapai.

c. Cukup, suatu kebijakan dapat mencapai hasil yang diharapkan dengan sumber daya yang ada.

d. Adil.

e. Terjawab, kebijakan dibuat agar dapat memenuhi kebutuhan suatu golongan atau suatu masalah tertentu dalam masyarakat. 
Tahap-tahap kebijakan publik menurut William Dunn (1995), adalah sebagai berikut (Anggara, 2018).

a. Penyusunan agenda Agenda setting adalah sebuah fase dan proses yang sangat strategi dalam realitas kebijakan publik. Dalam proses inilah ada ruang untuk memaknai masalah publik dan prioritas dalam agenda publik yang dipertarungkan. Jika sebuah isu berhasil mendapatkan status sebagai masalah publik dan mendapatkan prioritas dalam agenda publik, isu tersebut berhak mendapatkan alokasi sumber daya publik yang lebih.

b. Formulasi kebijakan merupakan tahap perumusan kebijakan, dan menyiapkan alternatif kebijakan yang dipilih sebagai sarana dalam memecahkan masalah

c. Legitimasi kebijakan merupakan memberikan otoritas pada proses dasar pemerintahan, tindakan legitimasi dalam suatu masy diatur oleh pemerintah

\section{METODE PENELITIAN}

Pengumpulan data pada penelitian ini menggunakan studi literatur yng merujuk pada tinjauan pustaka. Jenis data yang digunakan pada penelitian ini menggunakan data sekunder yang bersumber dari jurnal, penelitian terdahulu, buku, berita, dan media lainnya. Data tersebut digunakan penulis untuk melakukan analisis secara mendalam tentang pro dan kontra UU No. 8 Tahun 2016 tentang Penyandang Disabilitas.

\section{HASIL DAN PEMBAHASAN}

Kedudukan penyandang disabilitas dalam kehidupan sosial kemasyarakatan sering kali dipandang sebelah mata Tidak jarang kita juga melihat para penandang disabilitas ini memiliki kemampuan dan keahlian yang lebih dari orang yang memiliki fisik normal. Bahkan mereka bisa menciptakan sesuatu yang kreaktif dan inovatif, atau bahkan mampu menjuarai bidang olahraga. Adanya UU No.8 Tahun 2016 ini diharapkan dapat menjamin hak dan kesempatan untuk penyandang disabilitas 
terpenuhi, mulai dari hak pekerjaaan, pendidikan, hingga akses fasilitas umum. Disamping itu, didalam bidang politik dalam hal ini pemilu seharusnya ada fasilitas untuk penyandang disabilitas sebagai upaya untuk menjalankan demokratisasi di indonesia.

Menurut Maria Farida dalam (Nugroho, 2013) bahwa pengembangan ilmu di dalam perundang-undangan dapat mendorong fungsi pembentukan peraturan perundang-undangan yang sangat diperlukan kehadirannya, oleh karena itu dalam negara hukum, tujuan utama dari pembentukan undangundang bukan lagi untuk menciptakan kodifikasi bagi norma-norma dan nilainilai kehidupan, akan tetapi untuk menciptakan modifikasi atau perubahan dalam kehidupan masyarakat. Bisa diartikan bahwa saat ini, pembentukan undang-undang didasarkan kepada adanya perubahan pada dinamika masyarakat umum, yang mana aturan-aturan hukum sebelumnya tidak lagi sesuai, dan aturan hukum tersebut mengikuti perubahan yang ada.

Perubahan UU no. 4 tahun 1997 merupakan bukti keseriusan pemerintah dalam menangani masalah sosial seperti pemenuhan hak-hak penyandang disabilitas. Disamping itu, adanya kebaharuan dari undangundang terbaru mengingat dinamika sosial kemasyarakat terus berkembang mengikuti arus globalisasi yang semakin maju. Sehingga, masyarakat yang kekurangan dalam hal fisik maupun mental dapat berpartisipasi yang ditopang oleh hukum yang ada untuk menjamin kelangsungan hidupnya. Adapun proses perubahan UU No. 2 tahun 1997 menjadi UU No. 8 Tahun 2016 yaitu sebagai berikut (https://www.rappler.com/):

a. RUU penyandang disabilitas diajukan oleh Komnas HAM pada 2013 bulan Juni kepada Baleg, kemudian RUU menjadi usul inisiatif DPR RI yang akan menggantikan undang-undang nomor 4 tahun 1997 tentang penyandang cacat, dan menjadi Prolegnas 2014 pada urutan ke-57. Tetapi pembahasan berhenti dikarena DPR dalam masa reses mulai 6 Maret-Mei. Dan kemudian kembali menjadi Prolegnas 2015. 
b. Pada tahun 2015 pimpinan komisi VIII DPR RI meminta badan legislasi untuk melakukan pengharmonisasian, pembulatan, pemantapan konsepsi RUU tentang penyandang disabilitas. Kemudian badan legislasi melakukan kajian atas rancangan tersebut yang meliputi beberapa aspek pertama, aspek teknik yakni melihat pemenuhan syarat dari RUU yang diajukan ke dewan. Untuk kemudian dikoreksi beberapa hal salah satunya dalam hal EYD karena terdapat dari penulisan RUU masih banyak yang tidak sesuai dengan EYD sehingga diganti penulisannya saja. Selain itu, RUU penyandang disabilitas juga telah dilengkapi dengan naskah akademik sesaui dengan syarat tata tertib DPR. Kedua, aspek substansi dalam hal ini ada beberapa hal yang perlu untuk disempurnakan yang ada dalam pasalpasal dan tambahan-tambahan yang perlu ditambahkan untuk menunjang kelengkapan UU tersebut. Ketiga, asas pembentukan peraturan perundangundangan didalam RUU penyandang disabilitas telah memenuhi asas-asas dalam pembentukan perpu. Namun, masih perlu adanya penyempurnaan dari asas kejelasan rumusan dan asas yang dapat dilaksanakan.

c. Pembahasan RUU tidak melalui panitia khusus (pansus) diparlemen, tetapi hanya sebatas panitia kerja di komisi VIII

d. DPR mengesahkan RUU penyandang disabilitas menjadi Undang-undang pada sidang paripurna III 2015/2016

e. Selanjutnya setelah UU disahkan langkah berikutnya adalah merumuskan aturan lain yang menjadi turunan UU penyandang disabilitas yang diperkirakan ada 11 peraturan pemerintah yang akan disusun.

Jika dilihat dari proses pembuatan undang-undangan ini yaitu memperlukan waktu sekitar 3 tahun dalam mengesahannya menjadi undangundang, yang mana dimulai dari tahun 2013 pihak Komnas HAM mengajukan Draf RUU dan Naskah akademik dan baru bisa disahkan pada tahun 2016. Menurut (Trimaya, 2013) dalam penelitiannya lembaga legislatif periode 20092014 mengalami beberapa kendala-kendala dalam peleksanaan fungsi legislasi DPR RI masa bakti 2009-2014, yaitu pembahasan RUU yang lambat dan tidak 
efisien, hal ini terjadi karena jumlah hari legislasi yang hanya ditentukan 4 (hari) hari dalam satu minggu seringkali tidak mencukupi dan batasan jangka waktu pembahasan RUU sering tidak jelas, sehingga penyelesaian RUU tidak ada kepastian jangka waktunya. Pembahasan RUU berdasarkan Daftar Inventarisasi Masalah (DIM) juga menjadi penyebab dalam proses pembahasan RUU yang membutuhkan waktu yang panjang. DIM ini diajukan oleh pemerintah melalui menteri-menteri terkait, dalam hal ini yang berkaitan dengan penyandang disabilitas.

Menurut Moh. Mahfud MD dalam (Nugroho, 2013) pada negara demokrasi, rakyatlah yang menentukan hukum melalui wakil-wakilnya di parlemen yang dipilih langsung oleh rakyat sendiri. Kehendak mayoritas rakyat di dalam negara demokrasi menjadi kehendak negara, bahkan bisa menjadi hukum negara tanpa harus dipersoalkan baik buruknya. Proses pengesahan Undang-Undang Nomor 8 Tahun 2016 Tentang Peyandang Disabilitas, ini dalam proses pembuatannya seharus melibatkan para peyandang disabilitas. Karena mereka yang lebih mengetahui kebutuhan mereka, apalagi jika para legislatif bukanlah orang-orang penyadang disabilitas, yang tidak mengetahui apa yang dibutuhkan. Sebelumnya Undangundang Nomor 8 Tahun 2016 ini, dibentuk RUU nya yang diusulkan oleh Komnas HAM kemudian menjadi RUU usul inisiatif DPR. Sehingga dalam hal ini proses pembahasan dan pembuatannya pun melibatkan aktor seperti LBH Jakarta dan organisasi Himpunan Wanita Disabilitas Indonesia, dan Perhimpunan Jiwa Sehat. Organisasi-organisasi ini selalu memantau pembuatan peraturan perundang-undangan ini. Selain aktor-aktor tersebut DPR juga melibatkan pemerintah dalam pembahasan undang-undangan ini, pemerintah yang terlibat pun yaitu menteri-meneteri yang ada berkaitan dengan penyadang disabilitas.

Diluar pembahasan itu sendiri, ada juga Koalisi Organisasi Disabilitas Nasional yang terus menyampaikan suaranya terhadap hak-hak penyandang disabilitas kepada DPR. Salah satu pendpaat mereka adalah pembahasan RUU 
yang tidak melalui panitia khusus (pansus) di parlemen melainkan hanya sebatas panitia kerja (panja) di Komisi VIII. Menurut Koalisi Organisasi Disabilitas Nasional ini, maka kementerian yang berkewajiban memenuhi hak penyandang disabilitas bisa merasa lepas tanggungjawab. Akhirnya kewajiban negara hanya diemban oleh Kementerian Sosial (Kemensos) yakni Direktorat ODK, sehingga UU yang disahkan tidak menunjukkan pembaharuan. (http://nasional.republika.co.id/).

Selain itu Persatuan Peyandang Disabilitas Indonesia (PPDI) juga mengharapkan dalam pembahasan RUU disabilitas dilaksanakan oleh Panitia Khu sus bukan Komisi VIII DPR, karena 20 hak penyandang disabilitas pemangku kewajibannya adalah dari berbagai kementerian. Dalam mengkaji draf RUU ini juga, pihak Baleg DPR mengundang pakar dari universitasuniversitas terkemuka. Serta melakukan FGD dengan organisasi-organisasi penyandang disabilitas (http://www.dpr.go.id/berita/detail/id/7501).

Maka aktor-aktor yang terlibat dalam pembentuk peraturan perundangundang ini sebenarnya telah melibatkan berbagai lapisan, mulai dari DPR sendiri, pemerintah melalui menteri-menteri, Komnas HAM, organisasi yang bergerak dalam hal penyandang disabilitas, para akademisi, masyarakat penyandang disabilitas itu sendiri. Dalam prosesnya memang, lembaga legislatif melibatkan aktor-aktor penting baik dalam perumusan/pembahasan, serta pengesahan, namun apakah semua suara dari aktor-aktor ini didengarkan oleh lembaga legislatif? Mungkin, semua suara didengarkan oleh para legislator, namun tetap saja dalam mengambil suatu keputusan disesuaikan dengan kondisi, dan tetap usulan yang disampaikan oleh setiap orang dipertimbangkan untuk menjadi bagian dari peraturan yang ada.

Perubahan Undang-Undang Nomor 4 Tahun 1997 kepada UndangUndang Nomor 8 Tahun 2016 harus disesuaikan dengan dinamika masyarakat, khususnya kaum difabel, serta tidak dilepaskan dari UUD 1945 dan Pancasila. Hal-hal yang menjadi faktor perubahan peraturan perundang- 
undangan ini mengacu kepada UU Nomor 19 Tahun 2011 Tentang Pengesahan Convention On The Right of Person With Disabilities (Pengesahan Hak-Hak Penyandang Disabilitas). UU Nomor 4 Tahun 1997 sudah berusia 17 tahun yang tidak membawa perubahan bagi nasib penyandang disabilitas di Indonesia, tidak sesuai dengan keadaan saat ini, dan tidak sesuai dengan perkembangan hukum terkini.

Menurut Ledia Komisi VIII DPR RI perubahan UU No.4 Tahun 1997 perlu dilakukan karena undang-undang ini berparadigma pelayanan dan belas kasihan (charity based) sedangkan UU No. 8 Tahun 2016 berparadigma pemenuhan hak penyandang disabilitas, baik hak ekonomi, politik, sosial maupun budaya. Dimana harapan aturan ini menjadi pemenuhan, penghormatan, dan perlindungan atas hak-hak penyandang disabilitas (http://www.dpr.go.id/berita/detail/id/11528). Hadirnya undang-undang ini juga didasarkan kepada fasilitas umum yang tidak ramah atas pendayang difabel, sehingga ada batasan ruang gerak mereka, padahal seharusnya keberadaan mereka juga harus diakui dihapan publik, salah satunya dengan menyediakan sarana dan perasana sesuai kebutuhan mereka.

Faktor lainnya undang-undang dibentuk karena lingkungan sosial, atau bahkan lingkungan keluarga yang sering mengucilkan para kaum difabel ini, seperti diletakkan pada panti asuhan, dipasung, tidak diberi waktu untuk bermain di luar rumah bagi anak-anak, dan sebagainnya. Padahal peran keluarga yang sangat penting, dan yang lebih banyak memberikan motivasi kepada kaum difabel. Banyak penyandang difabel yang mampu berprestasi dan mendapatkan juara. Dan itu terbukti di berbagai pekan olahraga di Indonesia para penyandang difabel juga ikut serta, dan sebagain dari mereka mendapatkan juara. Maka untuk itu, kehadiran mereka bukan hal negatif, tetapi jadikan mereka sama seperti kita, agar para penyandang difabel ini terus mau maju dan berkembang, sesuai dengan peraturan ini, maka kita juga menghargai dan menghormati hak-hak mereka. 


\section{KESIMPULAN}

Undang-Undang Nomor 4 Tahun 1997 Tentang Penyandang Cacat diganti menjadi Undang-Undang Nomor 8 Tahun 2017 Tentang Penyandang Disabilitas. Pergantian peraturan perundang-undangan ini dikarenakan peraturan sebelumnya tidak sesuai dengan kondisi saat ini, peraturan sebelumnya juga menjadikan penyandang disabilitas sebagai objek yang belas kasihan. Walaupun ada UU No. 4 Tahun 1997, namun hak-hak asasi penyandang disabilitas belum teralisasikan, mereka dalam kehidupannya masing diasingkan dan selalu mendapatkan perilaku yang tidak adil. Maka melalui UU No. 8 Tahun 2016 ini, penyandang disabilitas memiliki kedudukan hukum dan hak asasi manusia yang sama sebagai warga negara Indonesia dan sebagai bagian yang tidak bdipisahkan dari masyarakat Indonesia. Hal ini disesuaikan dengan UU Nomor 19 Tahun 2011 Tentang Pengesahan Convention On The Right of Person With Disabilities (Pengesahan Hak-Hak Penyandang Disabilitas). PBB dalam hal ini juga menyepakati bahwa kita perlu menghormati dan menghargai hak-hak dari penyandang disabilitas.

Proses pembuatan UU No.8 Tahun 2016 ini tidak menjadi persoalan baik di lembaga legislatif, maupun di luar lembaga. Karena memang semua aktor sepakat bahwa memang perlu adanya perubahan dalam aturan hukum yang berkaitan dengan penyandang disabilitas. Walaupun dalam proses pengesaha RUU menjadi UU cukup memakan waktu sampai 3 tahun, walaupun RUU ini sudah menjadi Prolegnas DPR RI. RUU penyandang disabilitas ini, dalam pembahasannya melibatkan aktor-aktor yaitu organisasi yang bergerak pada hal penyandang disabilitas, akademisi, Komnas HAM, masyarakat penyandang disabilitas sendiri, dan juga pemerintah melalui menteri-menteri yang berkaitan.

\section{DAFTAR PUSTAKA}

Anggara, S. (2018). Kebijakan Publik. Bandung: Pustaka Setia Bandung. 
Jati, R. (2012). Partisipasi Masyarakat Dalam Proses Pembentukan UndangUndang Yang Responsif. Jurnal Rechts Vinding (Media Pembinaan Hukum Nasional), 1(3), 331.

Nugroho, W. (2013). Menyusun Undang-Undang Yang Responsif dan Partisipatif Berdasarkan Cita Hukum Pancasila (Drafting Responsive and Participative Regulation Based On Pancasila Law Idealism). Jurnal Legislasi Indonesia, 10(3), 210.

Rosadi, O. (2010). Hukum Kodrat, Pancasila dan Asas Hukum Dalam Pembentukan Hukum di Indonesia. Jurnal Dinamika Hukum, 10(3), 283.

Trimaya, A. (2013). Kinerja Fungsi Legislasi DPR RI Masa Bakti 2009-2014. Jurnal Legislasi Indonesia, 10(3), 246.

\section{Berita Online}

https://www.cnnindonesia.com/nasional/20160120041542-32-105434/dprdan-menteri-menteri-rapat-ruu-penyandang-disabilitas /

(Diakses minggu 12 juli, Pukul 10:30 WIB)

http://www.dpr.go.id/berita/detail/id/7501 (Diakses minggu, 12 November 2017, Pukul 11:47 WIB)

http://nasional.republika.co.id/berita/nasional/umum/16/03/18/o481lr359masyarakat-sipil-pesimistis-terhadap-uu-penyandang-disabilitas (Diakses minggu 12, 8 November 2017 Pukul 11:05 WIB)

https:/ /www.rappler.com/indonesia/ 126291-dpr-sahkan-uu-penyandangdisabilitas (Diakses Selasa, 07 November 2017 Pukul 12:45 WIB)

Undang-undang no. 8 tahun 2016 tentang Penyandang Disabilitas

Undang-undang no. 4 tahun 1997 tentang Penyandang Cacat 